\title{
Disextinction, Inc.
}

\section{For his biology project, Jason decided to resurrect the passenger pigeon.}

\section{Kathryn Cramer}

"D addy's!" shouted Erika, my brighteyed granddaughter, when she saw the new bears at the zoo. So many of the animals - moas, dodos, thylacines - have a fluorescent green gene with the copyright of my son Jason's company, Disextinction, Inc. Today we saw the newest: atlas bears, absent since the nineteenth century.

In 1999, when Jason was a toddler learning to talk, he asked to see the dodo birds at the zoo. "Go zoo see dodo birds! Go zoo see Barbarylions!" He was an animal kid. Selecting library books, he chose those with realistic faces of animals on the cover.

I had just read him Gone Forever! An Alphabet of Extinct Animals. I exchanged solemn glances with the children's librarian and explained: extinction is for ever. There were never going to be any more. These animals were all gone.

"All gone," he echoed earnestly. "So sad."

For days he pestered me: "Want quaggas! Want great auk!" I searched the web for animals he craved. I searched on Barbary lion, allegedly extinct since the 1920s. The preferred lions of ancient Roman arenas, they were bigger than the lions in the zoo. I don't know how to convey my shock when the search engine delivered links to recent photographs of Barbary lions rescued from an abandoned circus in Zanzibar.

I found a photograph of the last quagga, striped from head to midriff, which died in Amsterdam in the 1870s. I also found the Quagga Rebreeding Project, with recent photographs of rebred quaggas grazing on the grounds of a particle accelerator in South Africa. A plains zebra subspecies, the quagga was rebred from the living population.

As I dug deeper, the stories got weirder. Schoolboys in Hastings, New Zealand, held an academic conference on the possibility of cloning their school mascot, the huia bird, driven extinct by a 1920s hat craze. The assembled scientists set out to clone the huia.

In Thailand, there was a project to clone a magnificent 100 -year-old preserved white elephant for the king. When the Japanese woolly mammoth group got its tissue samples to reproduce, the living cells were to be sent to the white-elephant cloners.

I opened Jason a brokerage account and put in his and my Christmas money. My thought was to buy him stock in Disney or Mattel. Then I had a better idea. A company called Geron was down because they had

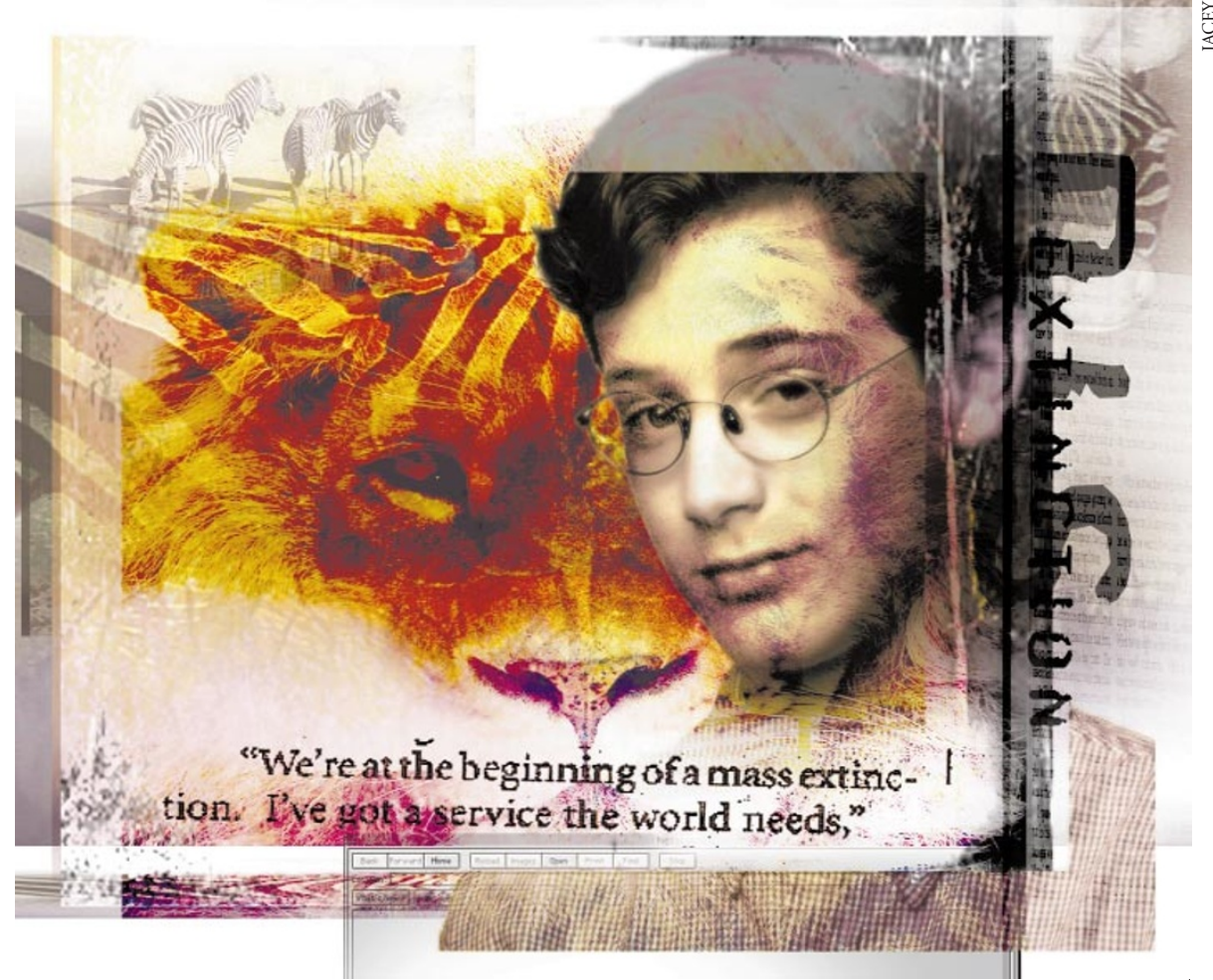

bought Roslin Labs - the Roslin that cloned Dolly the sheep. Bingo!

I bought him a hundred shares. I put more money into what I was thinking of as his college fund and bought other interesting biotech stocks: Abgenix, Affymetrix, Maxygen. Wall Street thought these stocks were interesting too. My son became quite wellto-do for a toddler.

When Jason was three, we drove to Florida to see his first Barbary lion. When he was four, we went to Africa to see quaggas. When he was five, we went to New Zealand to see fuzzy little huia chicks, born of magpies, and a herd of Enderby cattle, a breed that can live on a diet of seaweed, rebred from a single ageing cow and some frozen bull semen. When he was eight, we flew to Tokyo to see baby woolly mammoths. When he was 12 , we visited the Barbary Lion Refuge in the mountains of Morocco.

At 14, he decided to do some cloning of his own. For his biology semester project he chose the passenger pigeon. Because of the boom in livestock cloning, all the services he needed could be located through Enron Online's Biotech Market. Once he talked a tissue sample out of the Smithsonian, all he had to do was order services over the web and send and receive FedExes. Living chicks arrived by the semester's end.
Suddenly Jason was famous as the kid who'd cloned the passenger pigeon. He'd spent a third of his 'college fund' on eight passenger pigeon chicks. I was amazed and appalled. Then he got tissue samples from the Nationaal Natuurhistorisch Museum Leiden and spent the rest of his college fund cloning the great auk and, peculiarly, the quagga.

He sold his great auk chicks at a significant profit. The quagga colt he donated to the quagga rebreeding project. He incorporated, calling his company Disextinction, Inc. "We're at the beginning of a mass extinction. I've got a service the world needs," he said. When he was 19, Disextinction went public. By that time he was too busy for college.

When I see Erika cuddled up to Javanese tiger cubs in front of Jason's tank of exotic cichlids, I can't help but wonder what else Jason has added to their genetic makeup, how disextinct species differ from the originals.

Yesterday Disney bought the company. When Erika heard the news, her eyes grew large! She is so pleased.

Kathryn Cramer has co-edited the science fiction anthologies The Ascent of Wonder (Orbit) and Spirits of Christmas (Tor). She lives in Pleasantville, New York. 